\title{
Coherence of microbial respiration rate and cell-specific bacterial activity in a coastal planktonic community
}

\author{
Erik M. Smith* \\ University of Maryland Center for Environmental Science, Horn Point Laboratory, PO Box 775, Cambridge, Maryland 21613, USA
}

\begin{abstract}
The fluorogenic tetrazolium dye 5-cyano-2,3 ditolyl tetrazolium chloride (CTC) has been increasingly used as a measure of cell-specific metabolic activity in bacteria, in that it acts as an electron acceptor in the electron transport system (ETS) of bacterial cells. As such, it is taken to be a direct measure of abundance of those bacterial cells that are actively engaged in respiration. Although it would, thus, be anticipated that microbial sespiration should be strongly correlated to the number of CTC-active cells, such a relationship has yet to be demonstrated for natural bacterioplankton communities. CTC was used in situ to assay cell-specific respiratory activity within the pelagic community of Chesapeake Bay. Over the course of sampling, the observed variation in CTC-active cell abundance was 25 -fold, substantially greater than the 6 -fold variation in total cell abundance (estimated by DAPI staining). As a result, the proportion of CTC-active cells ranged from 3.5 to $47.4 \%$ of the total bacterial population, with this proportion varying seasonally as well as spatially. Both abundance and proportion of CTC-active cells were highly correlated with respiration rates within the microplankton community $(<3 \mu \mathrm{m}$ size fraction), explaining $80 \%$, or more, of the variations in these rates. Although respiration rates and total bacterial abundance also tended to covary seasonally, the relationship was not as strong, and large spatial differences in respiration along the Bay could not be explained by total abundance alone. This suggests that the large spatial/temporal variations previously observed in respiration rates are the result of changes in the number of active bacteria, rather than total bacterial abundance. Results of the present study thus encourage the view that CTC. provides an ecologically meaningful measure of active bacterial abundance in aquatic systems, and that CTC-active bacteria are likely responsible for the bulk of bacterial community metabolic activity.
\end{abstract}

KEY WORDS: Bacteria $\cdot$ CTC $\cdot$ Respiration

\section{INTRODUCTION}

Bacteria are responsible for the bulk of the heterotrophic activity in most aquatic environments (Pomeroy 1974, Cole et al. 1988). In planktonic systems, both total biomass (e.g. Cho \& Azam 1988, Fuhrman et al. 1989) and respiration rates (e.g. Williams 1981, Hopkinson et al. 1989) tend to be dominated by the bacterioplankton size fraction. Consequently, the bacterial community mediates a large fraction of the energy flow within these systems into respiratory losses (Pomeroy \& Wiebe 1988). Indeed, microbial respiration rate and bacterioplankton abundance tend to

•E-mail: emsmith@hpl.umces.edu covary when compared across a broad range of aquatic systems (del Giorgio et al. 1997a), or over long time and large space scales within a system (Tuttle et al. 1987). Such relationships, however, tend to break down when sampled at smaller scales (e.g. Jonas \& Tuttle 1990, Biddanda et al. 1994).

Natural bacterioplankton communities are often considered to be comprised of a homogeneous population with uniform physiological and ecological properties, so bacterial community processes such as growth and metabolism tend to be scaled to total cell abundance. Recently developed cell-specific assays, however, allow investigators to distinguish between metabolically active, dormant, and non-viable cells within natural bacterioplankton communities (e.g. Meyer-Reil 
1978, Zimmerman et al. 1978, Porter et al. 1995, Heissenberger et al. 1996). Across the range of methodologies employed, observations consistently reveal a relatively small, and variable, proportion of the total cell abundance that is metabolically active in natural assemblages (Tabor \& Neihof 1984, del Giorgio \& Scarborough 1995). Bacterial cells that take up and reduce the tetrazolium dye 5-cyano-2,3 ditolyl tetrazolium chloride (CTC) to its fluorescent formazan are presumed to have an active electron transport system (ETS). As activity within the ETS is essential to cellular respiration (Packard 1985), these CTC-reducing bacteria are typically referred to as 'actively respiring' (Rodriguez et al. 1992). A consistent feature of the CTC method, however, when used to measure the in situ activity of natural communities, is the low fraction of cells assessed as active. This fraction is typically less than 30\% (Choi et al. 1996, Sherr et al. 1998b). This implies that the small proportion of CTC-reducing cells are thus responsible for the bulk of respiratory activity within the total bacterial assemblages.

One test of the fidelity of the CTC method in yielding ecologically interpretable results in natural bacterioplankton communities would be to compare in situ variations in respiration rates with variations in abundance of both CTC-responsive bacteria and total bacteria. In the present study, parallel estimates of in situ respiration rates ( $<3 \mu \mathrm{m}$ size fraction) and bacterial abundances were made seasonally at stations along the axis of the Chesapeake Bay to test the hypothesis that respiration will correlate better with abundance of CTC-responsive bacteria than with total bacterial abundance. Chesapeake Bay is an ideal environment for such a comparison in that both respiration rates (Smith \& Kemp 1995) and bacterial production and abundance (Shiah \& Ducklow 1994) have been shown to vary greatly over both seasonal and spatial scales within this system.

\section{MATERIAL AND METHODS}

Sample collection. Sampling was performed during 3 research cruises within the Chesapeake Bay in spring (April 20 to 23), summer (July 11 to 14), and fall (October 30 to November 5) of 1997. For each research cruise a sampling transect ran the length of the salinity gradient in the mainstem portion of the Bay, from the landward end (approximately $39.5^{\circ}$ latitude) to the seaward end (approximately $37.0^{\circ}$ latitude). Each morning, between $07: 00$ and 10:00 h, water samples were collected for measurements of respiration rates and bacterial abundances at 2 adjacent stations, one in the deep central channel and one at a shallower lateral location of the same latitude.
Samples at each station were obtained from surface waters (1.5 to $2.0 \mathrm{~m}$ below air-sea interface) during morning hydrocasts using an array of Niskin bottles (20 1) mounted on a CTD (Neil Brown Instruments), which provided concurrent vertical profiles of temperature, salinity, oxygen, and in situ fluorescence. Immediately after completion of the hydrocast, water was gently siphoned into a low-density polyethylene carboy (Nalgene) then passed through gentle, gravityfeed, reverse filtration with a $142 \mathrm{~mm}$ diameter, $3.0 \mu \mathrm{m}$ pore size, polycarbonate (Poretics) membrane filter (cf. Williams 1981, Sampou \& Kemp 1994). This $3.0 \mu \mathrm{m}$ filtrate sample was used for all subsequent measurements of respiration rates and bacterial abundances.

Respiration measurements. Rates of planktonic community respiration within the $3.0 \mu \mathrm{m}$ filtrate were measured as changes in dissolved oxygen in replicate 6 to 10) $60 \mathrm{ml}$ glass BOD bottles. Sample water was gently siphoned from the reverse-filtration reservoir into BOD bottles (previously acid-washed, deionized water rinsed), which were filled and allowed to overflow twice, then capped with ground glass stoppers. Replicates for initial oxygen concentration were immediately fixed with Winkler reagents (Carritt \& Carpenter 1966). Half the replicate bottles were fitted with removable opaque sleeves and incubated in flowthrough deck incubators at in situ temperatures $\left( \pm 1^{\circ} \mathrm{C}\right)$ for a period of either $12 \mathrm{~h}$ (spring and fall cruises) or $6 \mathrm{~h}$ (summer cruise), after which they were fixed for final $\mathrm{O}_{2}$ concentrations. All oxygen concentrations were determined by Winkler titration of whole samples in the incubation bottle, with a commercial titration system (Sensoren Instrumente Systeme, Kiel, Germany) which uses a computer-controlled photometric endpoint detection system (Smith \& Kemp 1995). Measured hourly rates were multiplied by 24 , and rates were reported as $\mathrm{g} \mathrm{O}_{2} \mathrm{~m}^{-3} \mathrm{~d}^{-1}$.

Bacterial abundance and activity. The fluorogenic tetrazolium dye 5-cyano-2,3-ditolyl tetrazolium chloride (CTC; Polysciences, Inc.) was used to stain, for enumeration, bacteria with active ETSs (Rodriguez et al. 1992). The nucleic acid stain 4',6-diamidino-2 phenylindole (DAPI; Sigma Chemicai) was used to enumerate total bacteria populations (Porter \& Feig 1980). Duplicate subsamples of the $3.0 \mu \mathrm{m}$ filtrate water were taken, in parallel to the samples for respiration rate determinations, for the quantification of bacterial abundance estimates. Filtrate water $(5 \mathrm{ml})$ was placed into sterile $7 \mathrm{ml}$ plastic vials and inoculated with $50 \mathrm{mM}$ CTC solution, bringing the final concentration to $5 \mathrm{mM}$. Stock solutions of CTC were made fresh prior to use and stored at $4^{\circ} \mathrm{C}$ in the dark. Samples were then incubated in the dark for 8 to $10 \mathrm{~h}$ at in situ temperatures $\left( \pm 1^{\circ} \mathrm{C}\right)$. This staining protocol was adopted based on work by others (e.g. del Giorgio \& 
Scarborough 1995, del Giorgio et al. 1996) that showed this to be the optimum concentration and incubation time for expression of CTC activity.

After 8 to $10 \mathrm{~h}$, incubations were terminated by quick-freezing the sample vials in liquid nitrogen. Vials were subsequently stored at $-80^{\circ} \mathrm{C}$ until slides could be processed after completion of the cruise (cf. Choi et al. 1996, Sherr et al. 1998a). Once samples could be counted, the vials were thawed, and a subsample ( $3 \mathrm{ml}$ aliquot) was placed into a darkened filtering tower. The sample was counter-stained with DAPI (25 $\mu \mathrm{g} \mathrm{ml}^{-1}$ final concentration) for $10 \mathrm{~min}$, and filtered onto a $25 \mathrm{~mm}$ diameter, $0.2 \mathrm{~mm}$ black polycarbonate membrane filter (Poretics) under low vacuum.

Filters were counted immediately after mounting. Filters were examined at a final magnification of $1612 \times$ with a Zeiss Axiophot epifluorecence microscope equipped with a $100 \mathrm{~W}$ mercury lamp. The red fluorescence of CTC positive (CTC+) cells was visualized using a green excitation filter set (Zeiss 4877-14; excitation 510 to $560 \mathrm{~nm}$, barrier $590 \mathrm{~nm}$ ). For each preparation, at least 15 random fields were counted. The mean of these counts was used as the estimate of active bacteria for each replicate sample. Means of the 2 replicates for each station were averaged as the estimate of active bacteria for the sampling station. After enumeration of CTC+ cells, filter sets were exchanged and DAPI fluorescing cells were counted using a UV filter set (Zeiss 4877-02; excitation 365 nm, barrier $420 \mathrm{~nm}$ ) on the same slide preparation, counting a minimum of 10 random fields, and using the mean of the counts as the number of total bacteria in the sample.

There is an identification problem in that the fluorescence of reduced CTC is similar to the natural autofluorescence of photosynthetic picoplankton (Lovejoy et al. 1996, del Giorgio \& Scarborough 1995). This problem is compounded by the observation that the very largest bacterial cells tend to be the most active, as measured by CTC fluorescence (Gasol et al. 1995). To avoid any potential difficulties in distinguishing between CTC+ bacterial cells and picoautotrophic cells during the summer, abundances of photosynthetic picoplankton were enumerated separately using the natural autofluorescence of unstained microscopic preparations, counted under blue light (Zeiss 4877-09; excitation 450 to $490 \mathrm{~nm}$, barrier $520 \mathrm{~nm}$ ). Estimates of picoautotrophic cell counts were then subtracted from CTC fluorescence counts in which all pico-sized redfluorescing cells were enumerated (cf. del Giorgio \& Scarborough 1995). It was necessary to make this correction only in summer, when abundance of picoautotrophic cells tends to be significant (Malone et al. 1991, Marshall \& Nesius 1996).

\section{RESULTS}

\section{Total and active bacteria}

Total bacterial abundance, as measured by DAPI staining, varied both among stations within individual sampling cruises (i.e. spatially) and between sampling cruises (i.e. seasonally). The overall range in total bacterial estimates was from 2.1 to $12.6 \times 10^{9}$ cells $\mathrm{l}^{-1}$ (Table 1), with peak counts occurring during the July cruise. Estimates of the population of active bacteria, as measured by CTC staining, were always substantially lower than those of the total population of bacteria, ranging from 0.2 to $5.0 \times 10^{9}$ cells $\mathrm{l}^{-1}$. Thus, as a percentage of the total population, the mean proportion of active bacteria measured over the course of the entire study was $14.4 \%$, and ranged from a low of $3.5 \%$ during spring to a high of $47.4 \%$ during summer (Table 1).

While both total and active bacterial abundance showed spatial and temporal variation, the degree to which active bacterial abundance varied was always greater than that of the total bacteria. The coefficient of variation $(\mathrm{CV}, \%)$ for the entire data set was only $44.1 \%$ for the total bacteria population, but was $118.2 \%$ for the active bacteria. This represents a $25-$ fold difference in the abundance of CTC+ cells, compared to just a 6 -fold variation in total bacterial abundance. Even within individual cruises there was greater variation of active bacteria relative to total bacteria, with the $\mathrm{CV}$ of active bacteria being greatest in

Table 1. Mean, range, and coefficient of variation for bacterial abundances (total, CTC+, and \% CTC+) for the 3 sampling periods for the study, and all data combined

\begin{tabular}{|c|c|c|c|c|c|c|c|c|c|}
\hline \multirow[t]{2}{*}{$\begin{array}{l}\text { Sampling } \\
\text { cruise }\end{array}$} & \multicolumn{3}{|c|}{$\begin{array}{l}\text { Total bacteria } \\
\left(10^{9} \text { cells l-1 }\right)\end{array}$} & \multicolumn{3}{|c|}{$\begin{array}{l}\text { CTC }+ \text { bacteria } \\
\left(10^{9} \text { cells } l^{-1}\right)\end{array}$} & \multicolumn{3}{|c|}{$\begin{array}{c}\text { Proportion CTC+ } \\
\text { bacteria }(\%)\end{array}$} \\
\hline & Mean & Range & $\mathrm{CV}$ & Mean & Range & $\mathrm{CV}$ & Mean & Range & $\mathrm{CV}$ \\
\hline Apr & 5.80 & $4.1-7.3$ & 17.7 & 0.4 & $0.2-0.9$ & 52.9 & 6.5 & $3.5-13.9$ & 53.9 \\
\hline Jul & 9.40 & $5.0-12.6$ & 27.8 & 2.6 & $0.6-5.0$ & 53.3 & 26.6 & $11.8-47.4$ & 44.7 \\
\hline Oct/Nov & 4.10 & $2.1-5.5$ & 24.9 & 0.4 & $0.2-0.7$ & 34.3 & 10.1 & $6.7-19.2$ & 39.1 \\
\hline All data & 6.40 & $2.1-12.6$ & 44.1 & 1.1 & $0.2-5.0$ & 118.2 & 14.4 & $3.5-47.4$ & 79.9 \\
\hline
\end{tabular}




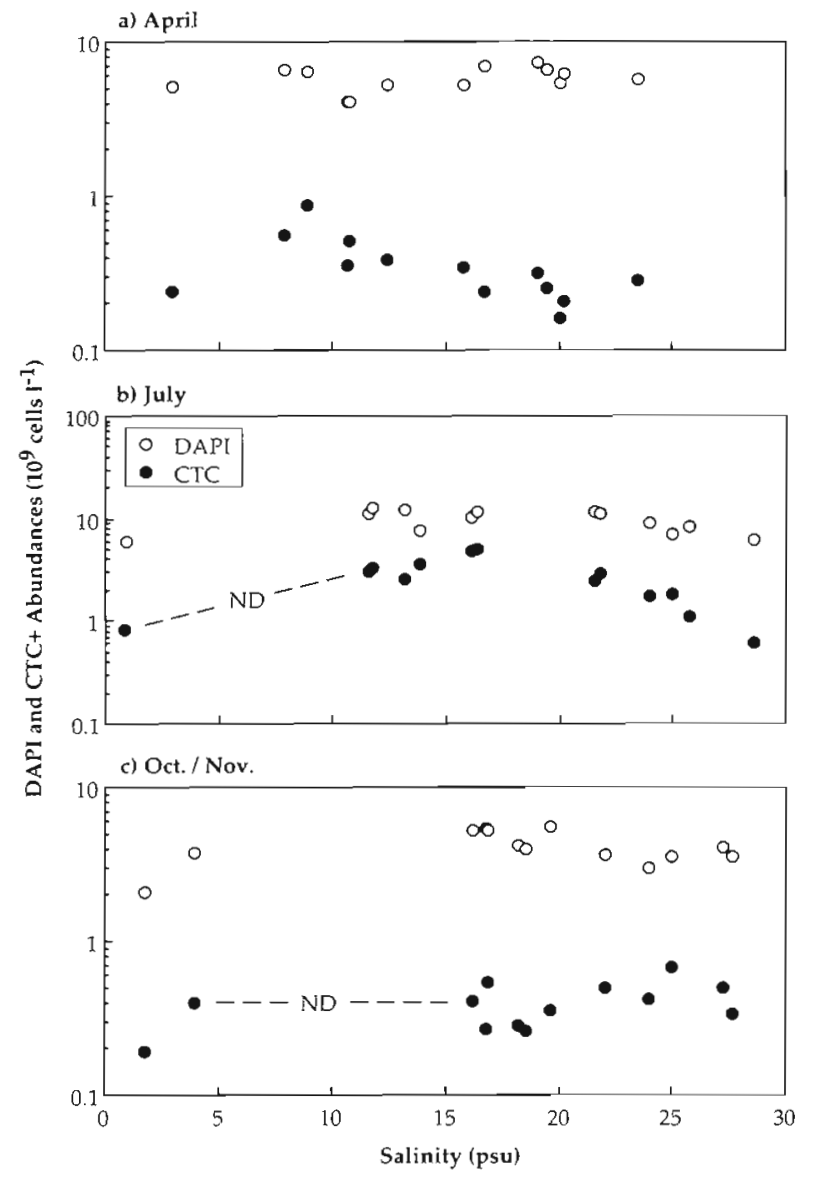

Fig. 1 Distribution of DAPI (0) and CTC+ (•) abundance along the salinity gradient in Chesapeake Bay for the 3 sampling cruises of 1997 Note scale change for the July cruise. ND: no data sampled within that portion of the salinity gradient

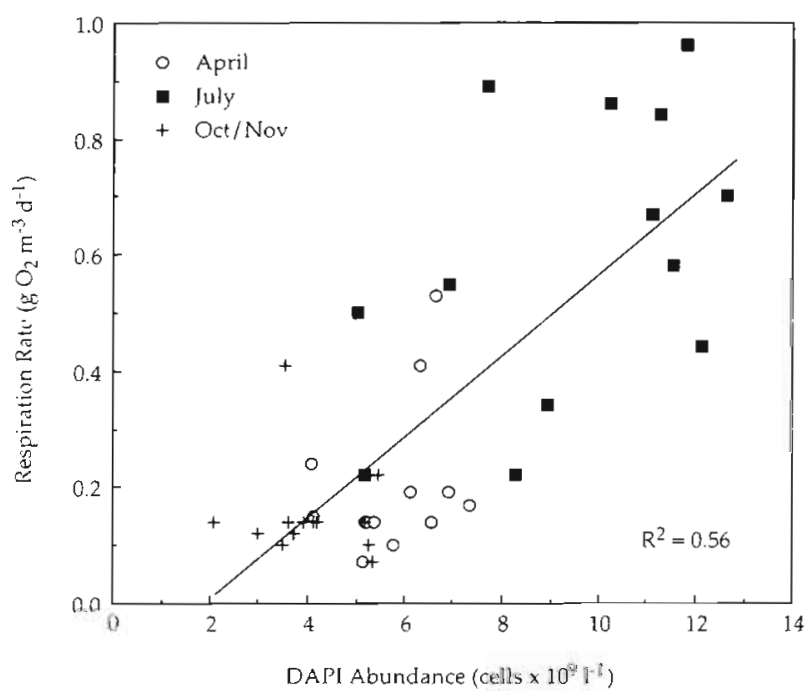

Fig. 2. Relationship between in situ respiration rate and total bacterial abundance, as measured by DAPI counts. Parameters of the regression equations are given in Table 3 spring and summer. This variation in active bacterial abundance was apparently not random, however. Abundance of active bacteria seemed to exhibit a clear spatial pattern during spring and summer (Fig. 1), where densities were low in the oligohaline 10 to 5 psu), peaked in the mesohaline reach (9 to $16 \mathrm{psu}$ ), then steadily decreased with increasing salinity. During the fall sampling cruise, when the CV of the active population was closer to that of the total population, there was no apparent spatial pattern in the distribution of active cells (Fig. 1c).

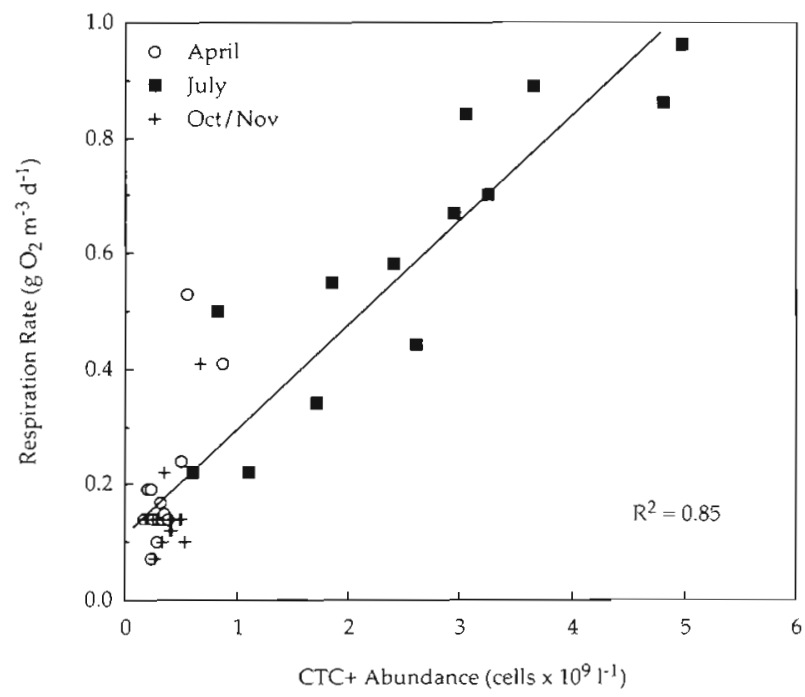

Fig. 3. Relationship between in situ respiration rate and the abundance of CTC active cells. Parameters of the regression equations are given in Table 3

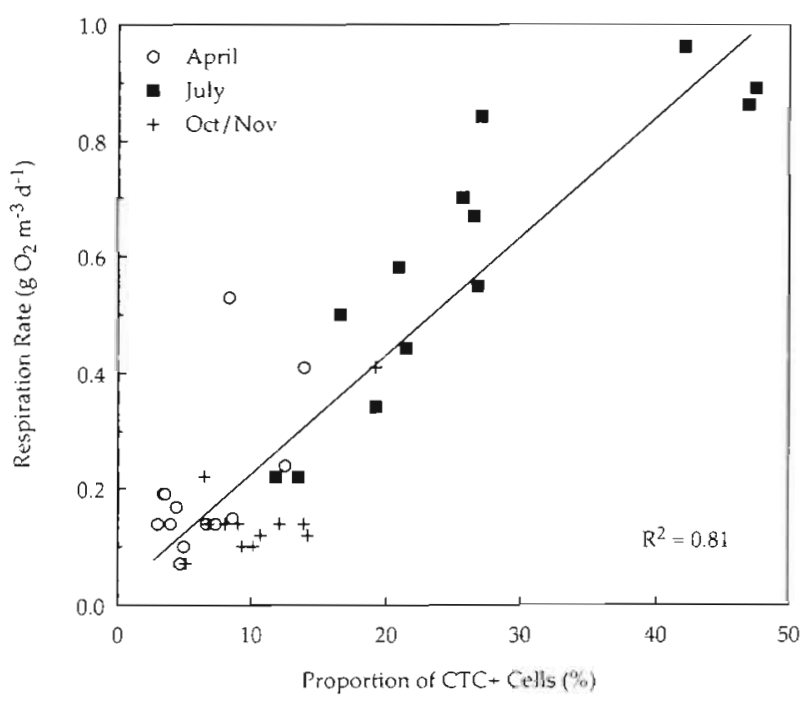

Fig. 4. Relationship between in situ respiration rate and the percentage of total abundance (DAPI counts) measured as active (CTC+ counts). Parameters of the regression equations are given in Table 3 


\section{Community respiration rates}

Respiration rates within the $<3 \mu \mathrm{m}$ plankton community ranged from 0.07 to $0.96 \mathrm{~g} \mathrm{O}_{2} \mathrm{~m}^{-3} \mathrm{~d}^{-1}$, and exhibited a seasonal pattern following trends in temperature (Table 2). As with bacterial abundances, respiration rates also showed considerable spatial variation within each cruise, with a degree of variation much greater than that of temperature. Although the range in respiration rates was greatest during the summer period, the lowest coefficient of variation was during this season, due to the high mean rates.

\section{Variation in bacterial abundances and respiration rates}

When considering the data set as a whole, there was a significant correlation between the abundance of active (CTC+) and total (DAPI) bacteria (Fig, 2, Table 3). Given the strong seasonality in all the variables examined (Tables $1 \& 2$ ), it is not surprising that temperature was a significant predictor of both active and total bacterial abundance, as well as respiration rates. Although there was a relation between total bacteria and respiration $\left(r^{2}=0.56\right)$, a substantially greater portion of the variability in respiration rates was explained by the abundance of active bacteria alone $\left(\mathrm{r}^{2}=0.85\right.$; Fig. 3$)$ or active bacteria as a percent of the total abundance $\left(\mathrm{r}^{2}=0.81\right.$; Fig. 4)

This relationship between abundance and respiration rates is driven largely by the summer data (Fig. 3), when the largest ranges were observed for all measured parameters, other than temperature (Tables $1 \& 2$ ). By confining the analysis to the summer data only, the ranges of variation are retained without the confounding effects of seasonality. For the summer experiment alone, temperature did not significantly predict (at the $p<0.01$ level) either bacterial abundance or respiration rate (Table 3). However, the relationship between respiration rates and active bacteria persists for the summer data, with the slope and intercept statistically indistinguishable from the whole data set ( $t$-tests at the $p<0.01$ level), and $r^{2}$ values approaching 0.80 . In contrast, variations in total abundance of the bacterioplankton for summer data only are no longer
Table 3. Parameters of linear regression analysis, for both all data combined and summer data separately, where $y$ is the dependent variable and $x$ is the independent variable. Values for regression equation intercept and coefficient are given with their standard error of the estimate. For regressions of all data, $\mathrm{n}=39$, for regressions of summer data only, $\mathrm{n}=13$

\begin{tabular}{|llclcc|}
\hline$y$ & $x$ & Intercept & Coefficient & $\mathrm{r}^{2}$ & $\mathrm{p}$ \\
\hline All data combined & & & & \\
CTC+ & Total & $-1.34 \pm 0.31$ & $0.38 \pm 0.04$ & 0.67 & $<0.0001$ \\
Resp & Total & $-0.13 \pm 0.07$ & $0.07 \pm 0.01$ & 0.56 & $<0.0001$ \\
Resp & CTC+ & $0.11 \pm 0.02$ & $0.18 \pm 0.01$ & 0.85 & $<0.0001$ \\
Resp & \%CTC+ & $0.02 \pm 0.03$ & $0.02 \pm 0.002$ & 0.81 & $<0.0001$ \\
Total & Temp & $0.69 \pm 0.98$ & $0.33 \pm 0.05$ & 0.51 & $<0.0001$ \\
CTC+ & Temp & $-1.86 \pm 0.40$ & $0.17 \pm 0.02$ & 0.63 & $<0.0001$ \\
Resp & Temp & $-0.23 \pm 0.09$ & $0.03 \pm 0.005$ & 0.55 & $<0.0001$ \\
& & & & & \\
Summer data only & & & & \\
CTC+ & Total & $-0.71 \pm 1.17$ & $0.35 \pm 0.12$ & 0.44 & $<0.0135$ \\
Resp & Total & $0.17 \pm 0.25$ & $0.04 \pm 0.03$ & 0.22 & $<0.1042$ \\
Resp & CTC+ & $0.18 \pm 0.07$ & $0.16 \pm 0.02$ & 0.79 & $<0.0001$ \\
Resp & $\%$ CTC+ & $0.11 \pm 0.09$ & $0.02 \pm 0.002$ & 0.78 & $<0.0001$ \\
Total & Temp & $0.47 \pm 22.96$ & $0.35 \pm 0.89$ & 0.01 & $<0.7031$ \\
CTC+ & Temp & $-15.53 \pm 10.92$ & $0.71 \pm 0.43$ & 0.20 & $<0.1250$ \\
Resp & Temp & $-3.65 \pm 1.79$ & $0.17 \pm 0.07$ & 0.34 & $<0.0371$ \\
& & & & & \\
\hline
\end{tabular}


found in the present study, which ranged from 2.1 to $12.6 \times 10^{9}$ cells $l^{-1}$, fall within the range reported by these previous reports, and likewise show a seasonal pattern of highest abundance during the summer sampling cruise. Thus, although there was considerable variation in total bacterial abundance over all stations and sampling dates, it was muted by comparison with other measured parameters (Table 1).

In contrast, CTC+ cell abundance, which ranged from 0.2 to $5.0 \times 10^{9}$ cells $\mathrm{l}^{-1}$, was significantly more variable than total cell abundance. This pattern of increased variation of active cells, which has also been seen for bacterioplankton in other aquatic systems (del Giorgio \& Scarborough 1995, Lovely et al. 1996), was evident both among and within cruises in the present study. There was a greater range in the number of active cells seen spatially within the summer cruise than there was when comparing cruise means across seasons. The spatial pattern observed for CTC+ abundance along the salinity gradient is consistent with previously reported measures of bacterial production in Chesapeake Bay (Shiah \& Ducklow 1994), suggesting enhanced microbial activity at intermediate salinities of the Chesapeake. This same spatial pattern has likewise been reported for respiration of the entire plankton community in this estuary (Smith \& Kemp 1995, Kemp et al. 1997).

As has been reported previously in all studies utilizing CTC, the proportion of active cells was rather low. When considered as a proportion of the total population, CTC+ bacteria ranged from a low of $3.5 \%$ of total bacteria in spring to a high value of $47.4 \%$ in summer. The overall mean for the study was roughly $14 \%$, a value which is typical of the results commonly found in other studies of natural bacterioplankton communities (e.g. del Giorgio \& Scarborough 1995, Gasol et al. 1995, Choi et al. 1996, del Giorgio et al. 1997b). Thus, it appears that most of the total bacterial assemblage within Chesapeake Bay is metabolically inactive, in terms of respiration, although the measure of activity reported here is lower than a measure of activity previously reported by Tabor \& Neihof (1984) for the mesohaline reach of the Chesapeake Bay. Using the non-fluorogenic tetrazolium dye 2 -(p-iodophenyl)-3( $p$-nitrophenyl)-5-phenyl tetrazolium chloride (INT), these authors reported percentage activities that ranged from 25 to $94 \%$. This discrepancy between INT and CTC measure of respiratory activity is consistent with observations made in culture studies that reduction of INT is less directly coupled to respiratory activity than is the reduction of CTC (Smith \& McFeters $1996,1997)$. Results of those studies suggest that INT, compared to CTC, is more likely to be reduced by agents other than the direct electron donors within the ETS itself. If correct, this would presume that CTC reduction should be a more appropriate measure of cellular respiratory activity per se, therefore leading to lower estimates of that fraction of the total population quantitatively engaged in respiratory metabolism.

Results of this study support the initial hypothesis that there would be a strong relationship between CTC+ bacteria and in situ respiration rates within the microbial community $\left(\mathrm{r}^{2}>0.80 ;\right.$ Table 3$)$. It is somewhat surprising, however, that respiration rates were also correlated with the proportion of total bacterial assemblage that was CTC+ (Fig. 4). There is no a priori reason that such a relationship should exist. The implication, however, is that high rates of respiration do not occur without a significant fraction of the bacterial community being active. On the other hand, there was also a significant relationship between total bacterial abundance and respiration rates (explaining $56 \%$ of the variation in respiration), when considering the data set as a whole. A similar relationship has been reported previously for seasonal studies within Chesapeake Bay (Tuttle et al. 1987).

The relationship between cell abundance and respiration for the entire data set is confounded by covariation with temperature (Table 3), which can profoundly influence heterotrophic processes in microplankton communities (Li \& Dickie 1987). The importance of temperature has been well documented for bacterial abundance (Shiah \& Ducklow 1994) and metabolic activity (Tabor \& Neihof 1984), as well as plankton community respiration (Sampou \& Kemp 1994, Smith \& Kemp 1995) in Chesapeake Bay. The confounding effects of temperature covariation were, however, removed by confining the analysis to a single cruise within which there was little spatial variation in temperature. The fact that respiration rates remained strongly correlated to the abundance of CTC+ cells during both summer and spring cruises clearly supports the interpretation that in situ microbial respiration is closely associated with the metabolism of active (CTC+) bacterioplankton cells. During the spring cruise, there was some variation in the 2 measures, and indeed there was a significant $\left(p<0.01, r^{2}=0.57\right)$ relation during this time as well, though not as robust as that of summer, when the range of variation was greatest. Thus, while temperature can be used as a predictor of respiration rates across seasonal scales (e.g. Smith \& Kemp 1995), results of this study show that variations in cell-specific bacterial activity serve to predict changes in respiration rate at small to intermediate spatial scales ( 1 to $100 \mathrm{~km}$ ), which have previously been less readily explained for coastal ecosystems such as Chesapeake Bay.

Rates of respiration measured in this study are those associated with organisms and particles in the $<3 \mu \mathrm{m}$ size fraction, and thus some portion of the respiration 
may be attributable to microorganisms other than bacteria. A rough estimate of the contribution by picoautotrophs to measured respiration rates was made using a published allometric relationship (Tang \& Peters 1995). Assuming a mean autotrophic cell diameter of $2 \mu \mathrm{m}$, cell-specific respiration rates would be approximately $0.15 \mathrm{pl} \mathrm{O}_{2}$ cell $^{-1} \mathrm{~h}^{-1}$. Over the range of autotrophic cell densities observed during the summer cruise, the contribution to measured respiration rates by autotrophic cells was always less than $5 \%$. The contribution of heterotrophic flagellates to the measured respiration rates cannot be quantified at this point, although most of these organisms in Chesapeake Bay are generally larger than $3 \mu \mathrm{m}$ (Dolan \& Coats 1990) Indeed, as the rates within the $<3 \mu \mathrm{m}$ size fraction are highly correlated to respiration rates measured within whole-water samples (Sampou \& Kemp 1994, Smith \& Kemp unpubl.), variations in CTC+ abundance can also serve as a significant predictor of respiration rates of the entire planktonic assemblage. Thus, it would appear that the cell-specific activity of the bacterial assemblage is a principal factor in the heterotrophic activity of the plankton community as a whole.

A potentially more important source of variation in the relationship between respiration rates and $\mathrm{CTC}_{+}$ cell abundance may be the method itself. It is likely that some portion of the bacteria that do not accumulate enough formazan to be detected by the CTC method via epifluorescence microscopy do, in fact, contribute to respiration. Variations in cell-specific rates of respiration among active cells themselves may also contribute to the overall variation in measured respiration rates. A recent study (Cook \& Garland 1997) concluded that short-term variations in respiration of bacterial cultures were better explained by the combined variation in both the number of CTC+ cells and the quantity of reduced formazan within those cells than by cell abundance alone. The use of flow cytometry, which is both a more sensitive measure of CTC reduction and allows for the quantification of cellspecific fluorescence intensity (e.g. del Giorgio et al. $1997 \mathrm{~b}$ ), may help resolve this issue of finer scales of variability within the community of active cells. The significant nature of the relationship (and high $\mathrm{r}^{2}$ value) seen in the present study, however, suggests that, at the level of variability seen in field samples of natural planktonic communities, the abundance of CTC+ cells is likely a dominant source of variation in explaining the distribution of respiration rates within these communities.

The finding of quantitative differences in respiration rates between bacterioplankton communities containing abundant CTC+ cells versus communities predominantly devoid of CTC+ cells lends strong support to the view that the CTC reduction method provides an ecologically meaningful measure of bacterial activity in aquatic systems (del Giorgio \& Scarborough 1995, Sherr et al. 1998b). This does not imply that cells incapable of reducing CTC are dead; however, it appears that there is a wide range of cell-specific activities occurring for bacterial assemblages in natural aquatic systems. Those cells which do not take up and reduce sufficient CTC to be scored as 'active' by the method are not necessarily completely devoid of cellular activ ity, and may indeed be taking up substrates, as measured by highly sensitive methods such as microautoradiography (e.g. Karner \& Fuhrman 1997). It has been shown that cells in starvation-survival mode must still sustain a basal metabolism to maintain cellular integrity (Morita 1982, 1997). It appears, however, that those cells that are responsive to the CTC method are responsible for the bulk of community processes such as production (e.g. del Giorgio et al. 1997b), as well as respiration (Fig. 3).

In summary, results of this study have clear implications for understanding the role of bacteria in the dynamics of plankton metabolism, and how this influences variations in the respiratory loss of carbon within pelagic ecosystems. The relationships observed in this study help to provide an explanation for meso-scale variations in observed respiration rates. While factors limiting planktonic primary production have been well studied (e.g. Boynton et al. 1982), environmental regulation of plankton community respiration rates are less well understood (e.g. Sampou \& Kemp 1994). Thus, the ability to relate the structure of the bacterial assemblage (i.e. active vs inactive) to its respiratory losses is an important step in understanding the organic carbon balance of planktonic communities. Furthermore, the results here have implications on how such respiratory loss processes are scaled to bacterial abundance. Results of this study argue that total bacterial abundance should be an inappropriate parameter in the cell-specific scaling of respiration rates. In the present study, cell-specific respiration rates, when scaled to CTC+ abundance, would be roughly 5- to 10-fold greater than those rates scaled to total bacterial abundance. Thus, while bacterioplankton communities should be considered an important sink for organic carbon (Ducklow et al. 1986), it should also be recognized that only a relatively minor component of these bacteria are actually responsible for the bulk of respiratory losses within pelagic communities.

Acknowledgements. I am gratefully indebted to W. M. Kemp for his support and, together with P. A. del Giorgio, for helpful discussions in the writing of this manuscript. Earlier drafts were enhanced by the helpful critical advice of 3 anonymous reviewers. Financial support and shiptime were provided by the NSF LMER/TIES Program (NSF grant number DEB9412113 amendment no. 003). Material supplies were made 
possible through a student research grant from the UMCES Horn Point Laboratory. I sincerely thank M. E. Mallonee for his assistance and camaraderie during research cruises, as well as the Crew of the RV 'Cape Henlopen'

\section{LITERATURE CITED}

Biddanda B, Opsahl S, Benner R (1994) Plankton respiration and carbon flux through bacterioplankton on the Louisiana shelf. Limnol Oceanogr 39:1259-1275

Boynton WR, Kemp WM, Keefe CW (1982) A comparative analysis of nutrients and other factors influencing estuarine phytoplankton production. In: Kennedy VS (ed) Estuarine comparisons. Academic Press, New York, p 69-90

Carritt DE, Carpenter JH (1966) Comparison and evaluation of currently employed modifications of the Winkler method for determining dissolved oxygen in seawater $;$ NASCO report. J Mar Res 24:286-318

Cho BC, Azam F (1988) Major role of bacteria in biogeochemical fluxes in the ocean's interior. Science 332:441-443

Choi JW, Sherr EB, Sherr BF (1996) Relation between presence-absence of a visible nucleoid and metabolic activity in bacterioplankton cells. Limnol Oceanogr 41:1161-1168

Cole JJ, Findlay S, Pace ML (1988) Bacterial production in fresh and saltwater ecosystems: a cross-system overview. Mar Ecol Prog Ser 43:1-10

Cook KL, Garland JL (1997) The relationship between electron transport activity as measured by $\mathrm{CTC}$ reduction and $\mathrm{CO}_{2}$ production in mixed microbial communities. Microb Ecol 34:237-247

del Giorgio PA, Cole JJ, Cimbleris A (1997a) Respiration rates in bacteria exceed phytoplankton production in unproductive aquatic systems. Nature 385:148-151

del Giorgio PA, Gasol JM, Vaque D, Mura P, Agusti S, Duarte CM (1996) Bacterioplankton community structure: protists control net production and the proportion of active bacteria in a coastal marine community. Limnol Oceanogr 41 : $1169-1179$

del Giorgio PA, Prairie YT, Bird DF (1997b) Coupling between rates of bacterial production and the abundance of metabolically active bacteria in lakes, enumerated using CTC reduction and flow cytometry. Microb Ecol 34:144-154

del Giorgio PA, Scarborough G (1995) Increase in the proportion of metabolically active bacteria along gradients of enrichment in freshwater and marine plankton: implications for estimates of bacterial growth and production rates. J Plankton Res 17:1905-1924

Dolan JR, Coats DW (1990) Seasonal abundances of planktonic ciliates and microflagellates in mesohaline Chesapeake Bay waters. Estuar Coast Shelf Sci 31:157-175

Ducklow HW, Peele ER, Hill SM, Quinby HL (1988) Fluxes of carbon, nitrogen, and oxygen through estuarine bacterioplankton. In: Lynch MP, Krome EC (eds) Understanding the estuary: advances in Chesapeake Bay research. Chesapeake Research Consortium Publication, Solomons, MD, p 511-523

Ducklow HW, Purdie DA, Williams PJleB, Davres JM (1986) Bacterioplankton: a sink for carbon in coastal marine plankton community. Science 232:865-867

Fuhrman JA, Sleeter ID, Carlson CA, Proctor LM (1989) Dominance of bacterial biomass in the Sargasso Sea and its ecological implications. Mar Ecol Prog Ser 57:207-217

Gasol JM, del Giorgio PA, Massana R, Duarte CM (1995) Active versus inactive bacteria: size-dependence in a coastal marine plankton community, Mar Ecol Prog Ser 128:91-97
Heissenberger A, Leppard GG, Herndl GJ (1996) Relationship between the intracellular integrity and the morphology of the capsular envelope in attached and free-living marine bacteria. Appl Environ Microbiol 62:4521-4528

Hopkinson CS, Sherr BE, Wiebe WJ (1989) Size fractionated metabolism of coastal microbial plankton. Mar Ecol Prog Ser 51:155-166

Jonas RB, Tuttle JH (1990) Bacterioplankton and organic carbon dynamics in the lower mesohaline Chesapeake Bay. Appl Environ Microbiol 56:747-757

Karner M, Fuhrman JA (1997) Determination of active marine bacterioplankton: a comparison of universal 16S rRNA probes, autoradiography, and nucleoid staining. Appl Environ Microbiol 63:1208-1213

Kemp WM, Smith EM, Marvin-DiPasquale M, Boynton WR (1997) Organic carbon balance and net ecosystem metabolism in Chesapeake Bay. Mar Ecol Prog Ser 150:229-248

Li WKW, Dickie PM (1987) Temperature characteristics of photosynthetic and heterotrophic activities: seasonal variations in temperate microbial plankton. Appl Environ Microbiol 53:2282-2295

Lovejoy C, Legendre L, Klein B, Tremblay JE, Ingram RG, Therriault JC (1996) Bacterial activity during early winter mixing (Gulf of St. Lawrence, Canada). Aquat Microb Ecol 10:1-13

Malone TC, Ducklow HW (1990) Microbial biomass in the coastal plume of Chesapeake Bay: phytoplankton-bacterioplankton relationships. Limnol Oceanogr 35:296-312

Malone TC, Ducklow HW, Peele ER, Pike SE (1991) Picoplankton carbon flux in Chesapeake Bay. Mar Ecol Prog Ser 78:11-22

Marshall HG, Nesius KK (1996) Phytoplankton composition in relation to primary production in Chesapeake Bay. Mar Biol 125:611-617

Meyer-Reil LA (1978) Autoradiography and epifluorescence microscopy combined for the determination of number and spectrum of actively metabolizing bacteria. Appl Environ Microbiol 36:506-512

Morita RY (1982) Starvation-survival of heterotrophs in the marine environment. Adv Microbiol Ecol 6:171-178

Morita RY (1997) Bacteria in oligotrophic environments. Chapman and Hall, NY

Packard TT (1985) Measurements of electron transport activity in microplankton. Adv Aquat Microbiol 3:207-261

Pomeroy LR (1974) The ocean's food web, a changing paradigm. BioSci 24:499-504

Pomeroy LR, Wiebe WJ (1988) Energetics of microbial food webs. Hydrobiologia 159:7-18

Porter J, Diaper J, Edwards C, Pickup R (1995) Direct measurements of natural planktonic bacterial community viability by flow cytometry. Appl Environ Microbiol 61:2783-2786

Porter KG, Feig Y (1980) The use of DAPI for identifying and counting aquatic microflora. Limnol Oceanogr 25:943-948

Rodriguez GG, Phipps D, Ishiguro K, Ridgway HF (1992) Use of a fluorescent redox probe for direct visualization of actively respiring bacteria. Appl Environ Microbiol 58:1801-1808

Sampou P, Kemp WM (1994) Factors regulating plankton community respiration in Chesapeake Bay. Mar Ecol Prog Ser 110:249-258

Sherr BF, Choi JW, Sherr EB (1998a) Dead or alive? A large fraction of ETS-inactive marine bacterioplankton cells, as assessed by reduction of CTC, can become ETS-active with incubation and substrate addition. Microb Ecol (in press)

Sherr BF, deI Giorgio PA, Sherr EB (1998b) Estimating abundance and single-cell characteristics of actively respiring bacteria via the redox dye, CTC. Aquat Microb Ecol (in press) 
Shiah FK, Ducklow HW (1994) Temperature and substrate regulation of bacterial abundance, production and specific growth rate in Chesapeake Bay, USA. Mar Ecol Prog Ser 103:297-308

Smith EM, Kemp WM (1995) Seasonal and regional variations in plankton community production and respiration for Chesapeake Bay. Mar Ecol Prog Ser 116:217-231

Smith JJ, McFeters GA (1996) Effects of substrates and phosphate on INT(2-( $p$-idophenyl)-3-(p-nitrophenyl)-5-phenyl tetrazolium chloride) and CTC (5-cyano-2,3-ditolyl tetrazolium chloride) reduction in Escherichia coli. J Appl Bacteriol 80:209-215

Smith JJ, McFeters GA (1997) Mechanisms of INT(2-(p-idophenyl)-3-( $p$-nitrophenylj-5-phenyl tetrazolium chloride) and CTC (5-cyano-2,3-ditolyl tetrazolium chloride) reduction in Escherichia coli. J Microbiol Meth 29: $161-175$

Editorial responsibility: Fereidoun Rassoulzadegan, Villefranche-sur-Mer, France
Tabor PS, Neihof RA (1984) Direct determination of activities for microorganisms of Chesapeake Bay populations. Appl Environ Microbiol 48:1012-1019

Tang EPY, Peters RH (1995) The allometry of algal respiration. J Plankton Res 17:303-315

Tuttle JH, Jonas RB, Malone TC (1987) Origin, development and significance of Chesapeake Bay anoxia. In: Majumdar SK, Hall LW, Austin HM (eds) Contaminant problems and management of living Chesapeake Bay resources. Pennsylvania Academy of Science, Philadelphia, p 442-472

Williams PJleB (1981) Microbial contribution to overall marine plankton metabolism: direct measures of respiration. Oceanol Acta 4:359-364

Zimmerman R, Iturriaga R, Becker-Birck J (1978) Simultaneous determination of the total number of aquatic bacteria and the number thereof involved in respiration. Appl Environ Microbiol 36:926-935

Submitted: February 26, 1998; Accepted: May 27, 1998 Proofs received from author(s): August 20, 1998 